\title{
Evaluation of NT-proBNP in children with heart failure younger than 3 years old
}

\author{
DANIELA IACOB ${ }^{1}$, ANGELA BUTNARIU $^{1}$, DANIEL-CORNELIU LEUCUȚA ${ }^{2}$, GABRIEL SAMAȘCA ${ }^{3}$, \\ DIANA DELEANU ${ }^{3}$, IULIA LUPAN ${ }^{4}$ \\ 1“"Iuliu Hațieganu” University of Medicine and Pharmacy Cluj-Napoca, Department of Pediatrics, III ${ }^{\text {rd }}$ Pediatric Clinic \\ 2“Iuliu Hațieganu” University of Medicine and Pharmacy Cluj-Napoca, Department of Medical Informatics and Biostatistics \\ 3"Iuliu Hațieganu" University of Medicine and Pharmacy Cluj-Napoca, Department of Immunology \\ 4“Babeş-Bolyai” University, Cluj-Napoca, Romania; Department of Molecular Biology and Biotechnology
}

\begin{abstract}
Introduction. Heart failure (HF) is characterized by neuroendocrine activation. The cardiac natriuretic hormones, including atrial natriuretic peptide (ANP) and brain natriuretic peptide (BNP), together with their related pro-peptides (proANP and proBNP) represent a group of peptide hormones produced by the heart. A normal NT-proBNP level has a high negative predictive value for heart failure. The use of NT-proBNP testing is helpful in diagnosing acute HF in the emergency care setting, allowing an early and optimal treatment. The purpose of this study is to assess the prognostic value of NT-proBNP in heart failure in children younger than 3 years old and to establish whether it correlates with the NYHA/Ross functional class and left ventricle systolic function.

Methods. We enrolled 24 consecutive children with HF due to congenital heart diseases and dilated cardiomyopathy. The serum levels of NT-proBNP were measured, all patients underwent echocardiography and left ventricle ejection fraction was calculated.

Results. The highest median value of NT-proBNP was recorded in patients with cyanotic heart diseases $(248.0 \mathrm{fmol} / \mathrm{mL}), \mathrm{p}=0.610$. NT-proBNP had a negative correlation with the ejection fraction of the left ventricle: Spearman's rank correlation coefficient was -0.165 .

Conclusions. NT-proBNP levels correlate with the severity of HF in infants and small children younger than 3 years old with heart failure due to congenital heart diseases and dilated cardiomyopathy.
\end{abstract}

Keywords: NT-proBNP, serum levels, congenital heart diseases, dilated cardiomyopathy, left ventricle ejection fraction.

\section{INTRODUCTION}

NT-proBNP is a ventricle distension and overload biomarker that can be used as early diagnostic tests in heart failure (HF) [1]. The concentrations of NT-proBNP are dependent on their synthesis, but also on their clearance and are highly influenced by the renal function. Increased values of the NT-proBNP have been shown to offer a high diagnostic accuracy in adult patients with both acute and chronic HF [2]. Establishing the degree of HF severity based on the intensity of the dyspnea, fatigue, palpitation or chest pain, features which represent the basis of NYHA/Ross classifications may sometimes be difficult in infants and small children [3]. NT-proBNP has been studied as a biomarker for the evolution and management of HF [4]. In a pediatric study it was shown that a single NT-proBNP measurement was associated with the severity of HF and dysfunction of the left ventricle in children with HF [5-6]. The echocardiographic measurement of the left ventricle function [7] and the determination of the natriuretic peptide levels provide essential prognosis information in patients with stable, advanced HF [8].

We hypothesize that in infants and toddlers with HF due to congenital heart diseases and dilated cardiomyopathy, the serum levels of NTproBNP are also correlated with the HF functional class, the type of heart disease and left ventricle ejection fraction (LVEF). In children younger than 3 years old, this hypothesis has not yet been tested. Considering these aspects, the aim of our study is to assess the median values of NT-proBNP in HF infants and toddlers and to establish their correlation with the NYHA/Ross functional class and left ventricle systolic function.

\section{MATERIAL AND METHODS}

The study has been carried out at the Department of Pediatrics, (The III ${ }^{\text {rd }}$ Pediatric Clinic, Cluj-Napoca), from "Iuliu Hațieganu" University of Medicine and Pharmacy, Cluj-Napoca, Romania. 
The study has been approved by the local ethics committee of the "Iuliu Hațieganu" University of Medicine and Pharmacy, Cluj-Napoca, Romania, in accordance with the Helsinki Declaration, and all the legal representatives of the children included in the study gave their informed consent. Children received the standard care for patients with $\mathrm{HF}$, consisting in diuretics, angiotensin-converting enzyme inhibitors, beta-blockers, and sometimes digoxin.

Patient charts were reviewed for information regarding age, sex, the cause of $\mathrm{HF}$, medication, HF functional class and echocardiographic data. All children with HF included in the study underwent Doppler echocardiography and the determination of the left ventricle ejection fraction (LVEF). The serum levels of NT-proBNP were determined in all the patients with HF from our study group. A total of 24 consecutive patients with HF secondary to congenital heart diseases and dilated cardiomyopathy were enrolled in the study (Table 1), and clinical data, echocardiographic and biochemical parameters were collected. Our including criteria consisted in the presence of HF due to congenital cyanotic and acyanotic heart diseases or dilated cardiomyopathy in children younger than 3 years old. We excluded HF patients who also associated renal failure (to avoid the interference with the real values of the cardiac biomarkers), patients with arrythmias, HF patients with sepsis and those with toxic injury of heart cells. The New York Heart Association (NYHA) classification used for children older than 6 years was replaced in our study by the Ross classification, used in infants and younger children [3].

Table 1

Heart diseases types of that associated Heart Failure

\begin{tabular}{||l|c||}
\hline \multicolumn{1}{|c|}{ Characteristic } & $\begin{array}{c}\text { Number (\%) } \\
(\mathbf{n = 2 4 )}\end{array}$ \\
\hline Tetralogy of Fallot & $3 / 24(12.5)$ \\
\hline Transposition of the Great Arteries & $2 / 24(8.33)$ \\
\hline Double Outlet Right Ventricle & $1 / 24(4.17)$ \\
\hline Ventricular Septal Defect & $3 / 24(12.5)$ \\
\hline Atrial Septal Defect & $2 / 24(8.33)$ \\
\hline Complete Endocardial Cushion Defect & $1 / 24(4.17)$ \\
\hline Patent Ductus Arteriosus & $2 / 24(8.33)$ \\
\hline Aortic Stenosis & $1 / 24(4.17)$ \\
\hline Coarctation of the Aorta & $2 / 24(8.33)$ \\
\hline Pulmonary Stenosis & $1 / 24(4.17)$ \\
\hline Mitral Regurgitation & $2 / 24(8.33)$ \\
\hline Anomalous Pulmonary Venous Return & $1 / 24(4.17)$ \\
\hline Dilated Cardiomyopathy & $3 / 24(12.5)$ \\
\hline
\end{tabular}

Echocardiography was performed on non sedated children by an experimented ultrasonographer, using a Medison Ultrasound System Sonoace $8000 \mathrm{EX}$, with a pediatric probe and the LVEF was calculated. Echocardiography and functional classification of HF were obtained within 2 days of the NT-proBNP sampling. NT-proBNP measurements were performed on the Dynex ELISA automatic analyzer. The tests were provided by DRG Diagnostics Inc. (Marburg, Germany).

Statistical analysis. Quantitative data was presented numerically by median with interquartile range for non normally distributed data, and graphically by box-plots. Normality of the data was checked with quantile-quantile plot and ShapiroWilk test. Qualitative data was presented by counts and percentages. Comparisons between three of more groups regarding quantitative variables were made with the Kruskal Wallis test for non normally distributed data. Then, post-hoc pairwise tests were performed with Tukey Kramer test. The Spearman correlation coefficient was used to assess the relationship between two non normally distributed variables.

For all statistical tests used, the chosen significance level alpha was 0.05 , and the two tailed $p$ values were computed. The statistical analysis was made in R Environment for statistical computing and graphics, version 1.15.1 ${ }^{\mathrm{i}}[9]$.

\section{RESULTS}

\section{Clinical characteristics of the study group}

The median age of the patients in our study group was 2.2 years (interquartile range, 3 weeks 3 years). The male to female ratio was $16 \mathrm{M}: 8 \mathrm{~F}$, showing an increased prevalence of the heart diseases in boys. HF was caused by congenital heart diseases in 21 patients and by dilated 
cardiomyopathy in 3 patients. In our study group, from the 24 subjects with HF, 15 patients had acyanotic heart diseases, 6 children presented cyanotic heart diseases and 3 patients had dilated cardiomyopathy.

\section{Comparison of HF clinical severity classes and NT-proBNP}

The distribution of the patients within the study group was: 8 patients with functional class II HF, 8 patients with class III HF, 6 patients with class I HF and only 2 patients with class IV HF. In our group, patients with HF class II had the youngest age, with a median age of 0.6 years old, followed by children with HF class IV, who had a median age of 1.4 years old. Patients with HF class I and HF class III presented a median age of 2.2 years old and 2.5 years old, respectively. All pairwise comparisons between the age of the four HF classes were not statistically significant. NT-proBNP presented in our HF study group a continuous increase of the median value (Table 2).

\section{Analyzing NT-proBNP values and heart disease type associated with $\mathrm{HF}$}

In our study group the NT-proBNP median value was highest in the patients with cyanotic heart diseases $(248.0 \mathrm{fmol} / \mathrm{mL})$, followed by the patients with dilated cardiomyopathy (193.3 $\mathrm{fmol} / \mathrm{mL}$ ). The lowest median value of NT-proBNP was recorded in the acyanotic heart diseases patients (Table 3 ).

\section{Associations between NT-proBNP values and echocardiographic measurement of $\mathrm{HF}$}

An analysis of the correlation between NTproBNP (fmol/mL) and LVEF (\%) has been performed and results are shown in Figure 1. R2 for the model with the two variables were: McFadden $=0.06$, CoxSnell $=0.08$, Nagelkerke $=0.10$. The area under the curve was 0.66 .

Table 2

Distribution of the patients with regard to the heart failure (HF) severity class, age and NT-proBNP values

\begin{tabular}{|c|c|c|c|c|c|}
\hline HF (no. patients) & I (6) & II (8) & III (8) & IV (2) & $\mathbf{p}$ \\
\hline Age (years) & $\begin{array}{c}2.2 \\
{[1.5-3]}\end{array}$ & $\begin{array}{c}0.6 \\
{[0.1-3]}\end{array}$ & $\begin{array}{c}2.5 \\
{[1.9-3]}\end{array}$ & $\begin{array}{c}1.4 \\
{[0.8-1.9]}\end{array}$ & 0.344 \\
\hline NT-proBNP fmol/mL) & $\begin{array}{c}95.6 \\
{[68.3-118.8]}\end{array}$ & $\begin{array}{c}157.2 \\
{[47.8-263.2]}\end{array}$ & $\begin{array}{c}373.2 \\
{[90.5-428.0]}\end{array}$ & $\begin{array}{c}498.9 \\
{[346.1-651.7]}\end{array}$ & 0.217 \\
\hline
\end{tabular}

Data is presented as median values (interquartile range).

Table 3

Heart Disease type and NT-proBNP values

\begin{tabular}{rcccc}
\hline Heart disease (no. patients) & Acyanotic (15) & Cyanotic (6) & Dilated Cardiomyopathy (3) & p \\
\hline NT-proBNP (fmol/mL) & 123.9 & 248.0 & 193.3 & $\mathbf{0}$ \\
& {$[60.9-355.4]$} & {$[135.7-1044.0]$} & {$[101.7-498.9]$} & \\
\hline
\end{tabular}

Data is presented by median (interquartile range).

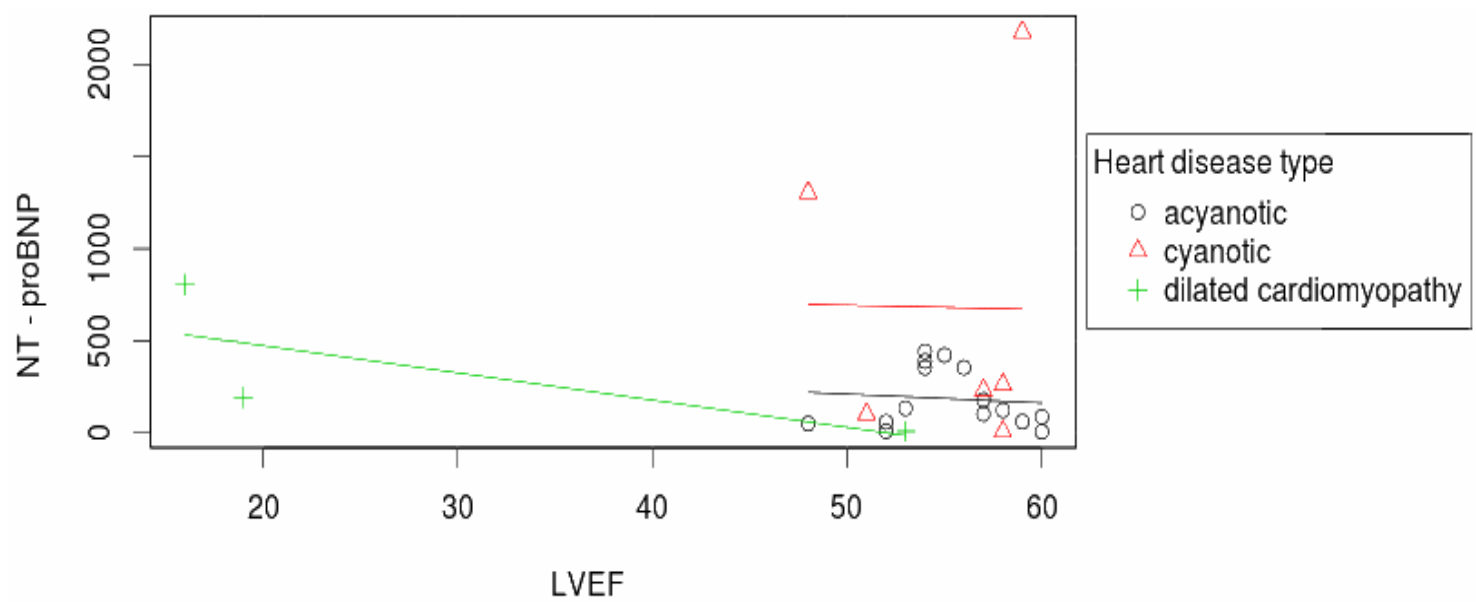

Figure 1. Relation between NT-proBNP (fmol/mL) and LVEF (\%). Spearman correlation coefficient values were $-0.04(p=0.89)$ for acyanotic, $0.17(\mathrm{p}=0.74$ for cyanotic $)$, and $-1(\mathrm{p}=0.33)$ for dilated cardiomyopathy. 


\section{DISCUSSION}

We used a control group (16 children younger than 3 years old) in our previous studies [1] on NTproBNP. The value obtained to that control group was $43.5 \mathrm{fmol} / \mathrm{mL}$. Our study revealed that the highest values of NT-proBNP were found in class III (373.2 fmol/mL) and IV (498.9 fmol/mL) HF patients, mostly in those having cyanotic heart diseases. We proved that the median value of NTproBNP increased as the HF classes have deteriorated and by combining these data with LVEF, we obtained important information for treatment decision.

Increased values of NT-proBNP may occur in heart muscle diseases, valve abnormalities, pulmonary hypertension, heart rhythm abnormalities, toxic injury to cardiac cells, sepsis [10]. NT-proBNP is superior to numerous clinical variables in predicting the risk in acute HF, including the NYHA/Ross symptom severity scale [11]. NT-proBNP reflects the severity of HF in children between 4 months and 14 years old [12]. Analyzing the performance of NT-proBNP measurements in diagnosing children with HF due to congenital heart defects and dilated cardiomyopathies, an increase in peptide levels correlated strongly with the severity of HF [13]. Biomarkers can offer an important tool for finding high risk patients before they develop HF symptoms [14]. A single NT-proBNP value on admission did not correlate with the severity of HF based on clinical scores and could not predict the need for mechanical circulatory support in children with acute, decompensated HF. Serial NT-proBNP levels can offer better tools in the decision for advanced therapeutic methods, including the need for mechanical circulatory support [15].

In a recent study, NT-proBNP in compensated patients with clinical HF and reduced ejection fraction versus $\mathrm{HF}$ patients with preserved ejection fraction were compared. Both HF patients with preserved ejection fraction and reduced ejection fraction had higher median levels of NT-proBNP (942 fmol $/ \mathrm{mL}$ and $2562 \mathrm{fmol} / \mathrm{mL}$ ). Also it was shown in the study that NT-proBNP distinguished HF with reduced ejection fraction from controls with an area under the curve (AUC) of 0.987 (P < 0.001) [16].

Further we will make a comparison with some studies performed on adult patients. Two different studies found significantly higher NTproBNP concentrations in patients with HF and reduced ventricle ejection fraction versus those with HF and preserved left ventricle ejection fraction. Measurements of NT-proBNP might track the progression of $\mathrm{HF}$ and allow assessing the response to medication. If one patient records progressive increase in serum NT-proBNP it might be necessary to introduce a more aggressive therapy $[17,18]$. Another study analyzing patients with chronic HF revealed that every time the plasma concentrations of NT-proBNP are doubled (relative to $125 \mathrm{fmol} / \mathrm{mL}$ ], the estimated hazard ratio increases with $56 \%$ for mortality and with $19 \%$ for hospitalization [19]. A recent review concluded that treatment of chronic HF guided by the aim of reducing NT-proBNP lower than prognostic meaningful concentrations can offer better outcomes [20].

NT-proBNP is a useful tool in the diagnosis of HF, the assessment of clinical severity and follow-up of pediatric heart diseases [21]. In HF patients with various forms of congenital heart diseases NT-proBNP is elevated and demonstrates useful diagnostic value. NT-proBNP concentrations are higher in children presenting congenital heart diseases with or without HF [22]. NT-proBNP measurements may be useful to stratify the risk for complications of these congenital heart diseases; it may also serve as an indicator for the timing of intervention. In young children with single ventricle congenital heart disease, plasma NT-proBNP represents a reliable test for clinical HF, defined by a Ross score $>2$, no matter the stage of palliation [23].

Future studies are needed to confirm these data. Limitations of the study are the small number of children, due to rare pathology. Other limitation of the study may be the fact that the study was performed in one university center.

\section{CONCLUSION}

In patients with HF NT-proBNP and echocardiography might provide diagnostic and prognostic information. The highest values of NT-proBNP were recorded in patients with the lower LVEF, but were not statistically significant. The combination 
of all these data may offer better tools to optimize the therapy in pediatric HF.

Acknowledgments. This study was financed by the Internal Grant in pediatrics No. 27020/10/15.11.2011 of
"Iuliu-Haţieganu" University of Medicine and Pharmacy, Cluj-Napoca, Romania.

Conflict of Interest disclosure: The authors declare that there are not conflicts of interest.

Introducere. Insuficiența cardiacă (IC) se caracterizează prin activare neuroendocrină. Hormonii natriuretici cardiaci, incluzând peptidul natriuretic atrial (ANP) şi peptidul natriuretic cerebral (BNP), impreună cu pro-peptidele lor corespunzătoare (proANP şi proBNP) reprezintă un grup de peptide - hormoni sintetizați de către inimă. $O$ valoare normală a NT-proBNP are o valoare predictivă negativă înaltă pentru insuficiența cardiacă. Determinarea valorii NTproBNP este utilă în diagnosticarea insuficienței cardiace acute în serviciile de urgență, permițând un tratament precoce şi optim. Studiul şi-a propus să evalueze valoarea prognostică a NT-proBNP în insuficiența cardiacă la copiii cu vârsta mai mică de 3 ani şi să analizeze dacă NT-proBNP se corelează cu clasa funcțională NYHA/Ross şi cu funcția sistolică a ventriculului stâng.

Metodologie. Am înrolat în studiu 24 copii internați consecutiv, având insuficiență cardiacă în cadrul malformațiilor cardiace congenitale şi al cardiomiopatiei dilatative. S-au determinat valorile serice ale NT-proBNP, toți pacientii au efectuat ecocardiografie şi a fost calculată fracția de ejecție a ventriculului stâng.

Rezultate. Valoarea mediană cea mai înaltă a NT-proBNP a fost decelată la pacienții cu afecțiuni cardiace cianogene (248.0 fmol $/ \mathrm{mL}$ ), $p=0.610$. NT-proBNP a documentat o corelație negativă cu fracția de ejecție a ventriculului stâng: puterea nivelului coeficientului de corelație a fost de -0.165.

Concluzii. Nivelele NT-proBNP se corelează cu severitatea insuficienței cardiace la sugari şi copiii mici cu vârsta mai mică de 3 ani având insuficiență cardiacă în cadrul malformațiilor cardiace congenitale şi al cardiomiopatiei dilatative.

Correspondence to: Dr. Samasca Gabriel, Department of Immunology,

"Iuliu-Hațieganu" University of Medicine and Pharmacy,

Croitorilor Street, 19-21 No, 400162 Cluj-Napoca,

E-mail: Gabriel.Samasca@umfcluj.ro

\section{REFERENCES}

1. BUTNARIU A., IANCU M., SAMASCA G., CHIRA M., LUPAN I. Changes in NT-proBNP in young children with congenital heart malformations. LabMedicine 2014; 45:43-47.

2. PRONTERA C., ZUCCHELLI G.C., VITTORINI S., STORTI S., EMDIN M., CLERICO A. Comparison between analytical performances of polyclonal and monoclonal electrochemiluminescence immunoassays for NT-proBNP. Clin Chim Acta 2009; 400:70-73.

3. ROSS R.D., BOLLINGER R.O., PINSKY W.W. Grading the severity of congestive heart failure in infants. Pediatr Cardiol 1992; 13:72-75.

4. RUSCONI P.G., LUDWIG D.A., RATNASAMY C., MAS R., HARMON W.G., COLAN S.D., et al. Serial measurements of serum NT-proBNP as markers of left ventricular systolic function and remodeling in children with heart failure. Am Heart J 2010; 160:776-783.

5. RATNASAMY C., KINNAMON D.D., LIPSHULTZ S.E., RUSCONI P. Associations between neurohormonal and inflammatory activation and heart failure in children. Am Heart J 2008; 155:527-533.

6. ARQUES S. Contribution of natriuretic peptide testing and Doppler echocardiography at bedside to the diagnosis of acute heart failure. A practical overview. Minerva Cardioangiol 2012; 60:385-394.

7. BUTNARIU A., ZAMFIR M., IANCU M., IACOB D., SAMASCA G., LUPAN I. Systolic and Diastolic Function in Congestive Heart Failure Pediatric Patients. Rom J Intern Med 2016:54:37-46. 
8. HINDERLITER A.L., BLUMENTHAL J.A., O'CONNER C., ADAMS K.F., DUPREE C.S., WAUGH R.A., et al. Independent prognostic value of echocardiography and N-terminal pro-B-type natriuretic peptide in patients with heart failure. Am Heart J 2008; 156:1191-1195.

9. R CORE TEAM. R: A language and environment for statistical computing. R Foundation for Statistical Computing, Vienna, Austria, 2012. ISBN 3-900051-07-0.

10. BAGGISH A.L., VAN KIMMENADE R.R., JANUZZI J.L. The differential diagnosis of an elevated amino-terminal pro-B-type natriuretic peptide level. Am J Cardiol 2008; 101:43-48.

11. BAGGISH A.L., VAN KIMMENADE R.R., JANUZZI J.L. Amino-Terminal Pro-B-Type Natriuretic Peptide Testing and Prognosis in Patients with Acute Dyspnea, Including Those with Acute Heart Failure. Am J Cardiol 2008; 101:49A-55A.

12. SUGIMOTO M., MANABE H., NAKAU K., FURUYA A., OKUSHIMA K., FUJIYASU H., et al. The role of N-terminal pro$B$-type natriuretic peptide in the diagnosis of congestive heart failure in children. Correlation with the heart failure score and comparison with B-type natriuretic peptide. Circ J 2010; 74:998-1005.

13. ŞAHIN M., PORTAKAL O., KARAGÖZ T., HASÇELIK G., ÖZKUTLU S. Diagnostic performance of BNP and NT-ProBNP measurements in children with heart failure based on congenital heart defects and cardiomyopathies. Clin Biochem 2010; 43:1278-1281.

14. KANTOR P.F., RUSCONI P., LIPSHULTZ S., MITAL S., WILKINSON J.D., BURCH M. Current applications and future needs for biomarkers in pediatric cardiomyopathy and heart failure: Summary from the Second International Conference on Pediatric Cardiomyopathy. Prog Pediatr Cardiol 2011; 32:11-14.

15. WONG D.T., GEORGE K., WILSON J., MANLHIOT C., MCCRINDLE B.W., ADELI K., et al. Effectiveness of serial increases in amino-terminal pro-B-type natriuretic peptide levels to indicate the need for mechanical circulatory support in children with acute decompensated heart failure. Am J Cardiol 2011; 107:573-578.

16. SANTHANAKRISHNAN R., CHONG J.P., NG T.P., LING L.H., SIM D., LEONG K.T., et al. Growth differentiation factor 15, $S T 2$, high-sensitivity troponin $T$, and N-terminal pro brain natriuretic peptide in heart failure with preserved vs. reduced ejection fraction. Eur J Heart Fail. 2012:14:1338-1347.

17. NIETHAMMER M., SIEBER M., VON HAEHLING S., ANKER S.D., MUNZEL T., HORSTICK G., et al. Inflammatory pathways in patients with heart failure and preserved ejection fraction. Int J Cardiol 2008; 129:111-117.

18. DE DENUS S., LAVOIE J., DUCHARME A., O'MEARA E., RACINE N., SIROIS M.G., et al. Differences in biomarkers in patients with heart failure with a reduced vs a preserved left ventricular ejection fraction. Can J Cardiol 2012; 28:62-68.

19. SCHOU M., GUSTAFSSON F., CORELL P., KISTORP C.N., KJAER A., HILDEBRANDT P.R. The relationship between $N$-terminal pro-brain natriuretic peptide and risk for hospitalization and mortality is curvilinear in patients with chronic heart failure. Am Heart J 2007; 154:123-129.

20. JANUZZI J.L. The role of natriuretic peptide testing in guiding chronic heart failure management: review of available data and recommendations for use. Arch Cardiovasc Dis 2012; 105:40-50.

21. CANTINOTTI M., CLERICO A., MURZI M., VITTORINI S., EMDIN M. Clinical relevance of measurement of brain natriuretic peptide and $N$-terminal pro-brain natriuretic peptide in pediatric cardiology. Clin Chim Acta. 2008; 390:12-22.

22. JOHNS M.C., STEPHENSON C. Amino-terminal Pro-B-type natriuretic peptide testing in neonatal and pediatric patients. Am J Cardiol 2008; 101:76-81.

23. LOWENTHAL A., CAMACHO B.V., LOWENTHAL S., NATAL-HERNANDEZ L., LISZEWSKI W., HILLS N.K., et al. Usefulness of B-type natriuretic peptide and N-terminal pro-B-type natriuretic peptide as biomarkers for heart failure in young children with single ventricle congenital heart disease. Am J Cardiol 2012; 109:866-872.

Received August 16, 2016 